\title{
Settlement and recruitment of the New Zealand sea urchin Evechinus chloroticus
}

\author{
M. D. Lamare* ${ }^{*}$ M. F. Barker \\ Department of Marine Science, University of Otago, PO Box 56, Dunedin, New Zealand
}

\begin{abstract}
Settlement and recruitment of the sea urchin Evechinus chloroticus was determined by a series of field and laboratory experiments on the South Island of New Zealand. Using settlement samplers, we monitored settlement of larvae at 1 to 2 mo intervals during 1992, 1993 and 1994. Recruitment over the same period was monitored from 3 to 8 mo intervals by quantifying both the density and percentage in the population of recruits (juveniles $<20 \mathrm{~mm}$ test diameter). Settlement and recruitment were higher in Doubtful Sound (SE South Island) than in Tory Channel (NE South Island). For Doubtful Sound, a large settlement between August 1992 and February 1993 (up to 1.14 settlers sampler ${ }^{-1} \mathrm{~d}^{-1}$ ) was followed by an increase in recruit density from 2.1 to 13.8 recruits $20 \mathrm{~m}^{-2}$ during the subsequent 9 mo (November 1992 to August 1993). Settlement during the following 2 yr was lower $\left(<0.12\right.$ sampler $\left.^{-1} \mathrm{~d}^{-1}\right)$, during which time the density of recruits decreased from 13.8 to 2.1 recruits $20 \mathrm{~m}^{-2}$. A similar pattern was found in Tory Channel where a lower settlement intensity was observed in $1992\left(<0.05\right.$ sampler $\left.^{-1} \mathrm{~d}^{-1}\right)$ and the density of recruits over the following year was less than 0.6 individuals $20 \mathrm{~m}^{-2}$. In 1993, settlement was up 10-fold to 0.54 recruits sampler s $^{-1}$ $\mathrm{d}^{-1}$, and the density of recruits increased from 0.3 to 5.0 juveniles $20 \mathrm{~m}^{-2}$ during the following $5 \mathrm{mo}$. The correlation between settlement and recruitment is described by the linear relationship, $y=1.4+$ $0.14 x$, where $y=$ annual recruitment (individuals $<20 \mathrm{~mm}$ TD $20 \mathrm{~m}^{-2}$ ) and $x=$ annual settlement (total number of settlers on samplers). Settlement and metamorphosis behavior of competent larvae was examined in the laboratory. Larvae show a preference for natural substrates (i.e. Coralline algae $>$ oyster shell > aged rock > aged plastic) and for surfaces with older biofilms. Given the findings of the current research, settlement samplers may be one tool that can increase our understanding of relative settlement intensity and other recruitment processes in E. chloroticus, and aid in the sustainable management of this species.
\end{abstract}

KEY WORDS: Evechinus chloroticus · Echinoid · Settlement · Recruitment $\cdot$ Larvae $\cdot$ Population dynamics $\cdot$ Fisheries

Resale or republication not permitted without written consent of the publisher

\section{INTRODUCTION}

Recruitment of marine invertebrates with a planktonic larval stage can be broadly divided into 3 components: (1) pre-settlement process comprising larval production and larval development, mortality and transport; (2) settlement and metamorphosis; and (3) post-settlement growth and mortality of juveniles. Quantifying the various components of recruitment in a population is difficult even when it is well estab-

*E-mail: miles.lamare@stonebow.otago.ac.nz lished that pre-settlement processes (i.e. larval supply) and recruitment are closely linked (Butman 1987, Underwood \& Fairweather 1989). By quantifying settlement and recruitment rate within a population, the importance of pre-settlement, settlement, and postsettlement processes can be better assessed.

Obtaining an accurate measure of settlement is problematic due to large spatial and temporal variations in the dispersion of larvae (Gaines \& Bertness 1993) and high mortality of newly settled individuals (Keogh \& Downes 1982, Rowley 1989, 1990). One method of integrating settlement of larvae over a period of time is to use settlement samplers (Harrold et 
al. 1991, Keesing et al. 1993, Ebert et al. 1994, Wing et al. 1995, Harris \& Chester 1996, Miller \& Emlet 1997). These samplers work by providing an artificial environment for competent larvae to settle onto and subsequently survive until the time when the samplers are retrieved. If the rate of settlement of larvae onto the samplers, and the subsequent survival rate of newly settled urchins were both $100 \%$, then deploying the samplers over a given time would provide an integrated measure of settlement intensity over that period. More importantly, if metamorphosis and survival of new settlers on samplers do not vary over time and space, then settlement samplers will provide a relative estimate of spatial and temporal patterns of settlement intensity.

Settlement samplers will underestimate larval supply because settlement and metamorphosis on artificial substrates, and post-settlement survival will be less than $100 \%$. The application of samplers to the study of recruitment must therefore be accompanied by an assessment of the relationship between settlement on the samplers and recruitment rates within each population. In turn, interpreting settlement patterns requires an understanding of settlement and metamorphosis behaviour of larvae on natural and artificial substrates.

Sea urchin fisheries are typically over-exploited (Keesing \& Hall 1998), which is often a consequence of a poor understanding of recruitment processes of the target species. Quantifying recruitment processes is therefore essential for sustainable management of these species. Here, we examine settlement and recruitment in the New Zealand sea urchin, Evechinus chloroticus Valenciennes (Echinoidea: Echinometridae). Larvae of E. chloroticus are obligate planktivores that occur in the water column in the Austral summer months of November through April. Larvae reach competency as early as $21 \mathrm{~d}$ in the laboratory (Lamare \& Barker 1999) and between 3 and 6 wk within Doubtful Sound (Lamare 1997, Lamare \& Barker 1999). In this paper we; (1) quantify settlement and metamorphosis behavior of competent larvae on natural and artificial substrates; (2) test 3 settlement sampler designs; and (3) compare settlement on samplers and recruitment rates in 2 populations over a $3 \mathrm{yr}$ period. In light of these findings, settlement processes in E. chloroticus, and their implications for the management of this sea urchin are discussed.

\section{MATERIALS AND METHODS}

Study sites. The 2 populations of Evechinus chloroticus examined occur in 2 extensive sounds located at opposite ends of the South Island of New Zealand
(Fig. 1). The north-eastern population occurs in Titi Bay $\left(174^{\circ} 11^{\prime} 40^{\prime \prime} \mathrm{E}, 41^{\circ} 14^{\prime} 15^{\prime \prime} \mathrm{S}\right)$ within Tory Channel, part of the Marlborough Sounds, a drowned valley system covering over $300 \mathrm{~km}^{2}$. Tory Channel is $20 \mathrm{~km}$ long, has an average width of $2 \mathrm{~km}$, a maximum depth of $50 \mathrm{~m}$, and a semi-diurnal tidal cycle with a vertical range of $1.3 \mathrm{~m}$. Water exchange in the channel is tidally driven. The channel is open at both ends with water entering from the eastern side from Cook Strait through Perano Heads, exiting into Queen Charlotte Sound through Dieffenbach Point, and returning to Cook Strait on the west via Queen Charlotte Sound (Heath 1974). Current flows through the channel are extremely high (up to $340 \mathrm{~cm} \mathrm{~s}^{-1}$, Heath 1974). In Titi Bay, E. chloroticus are patchily distributed subtidally on a moderately sloping rocky reef. The dominant macrophytes are Macrocystis pyrifera and Carpophyllum maschalocarpum.

The south-western population occurs at Espinosa

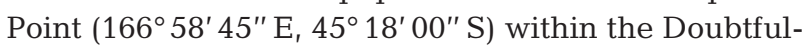
Thompson-Bradshaw Sound complex. This complex is approximately $110 \mathrm{~km}$ long and $2 \mathrm{~km}$ wide, with a $40 \mathrm{~km}$ main channel and 5 secondary arms. Depths within the fiord are relatively great, with a number of basins deeper than $300 \mathrm{~m}$. The fiord has 2 openings to the ocean, the primary entrance (Doubtful Sound) being $\sim 2 \mathrm{~km}$ wide and the second (Thompson Sound), $\sim 1 \mathrm{~km}$ wide. Shallow sills ( 60 to $100 \mathrm{~m}$ depth) are present at both entrances. The hydrography of Doubtful Sound is complex. The seaward movement of a low salinity surface layer out of the fiord at speeds up to $60 \mathrm{~cm} \mathrm{~s}^{-1}$ drives a compensatory flow of deeper seawater into the fiord, resulting in an estuarine circulation pattern, typical of the hydrography of many fiords (Pickard \& Emery 1982). Wind forcing and rain events modify this pattern, with up-fiord wind resulting in a geostrophic flow of water out of the fiord. Typical current speeds of between 5 to $13 \mathrm{~cm} \mathrm{~s}^{-1}$ at a depth of $15 \mathrm{~m}$ occur in the vicinity of Espinosa Point (Lamare 1998). The tidal cycle at Espinosa Point is semi-diurnal and has a maximum vertical range of $1.4 \mathrm{~m}$. Evechinus chloroticus occur subtidally on a moderately sloping reef of bedrock and cobble/bolder fields. The algae Ulva lactuca, Corallina spp., Ecklonia radiata, Codium fragile and Carpophyllum flexuosum dominate the flora.

Larval settlement behavior experiments. Evechinus chloroticus larvae were reared at $15^{\circ} \mathrm{C}$ in 3 replicate 51 beakers (2 larvae $\mathrm{ml}^{-1}$ ) stirred continuously with plastic paddles to keep larvae and food suspended in the seawater. Every $2 \mathrm{~d}$ water was changed and the larvae fed Dunaliella primolecta (8000 cells $\mathrm{ml}^{-1}$ ). Development from fertilization to metamorphic competency was completed in $20 \mathrm{~d}$. At this time, a range of artificial and natural substrates were tested for settlement pref- 
erences. Artificial substrates were prepared from white light diffuser PVC plastic that was cut into $25 \times$ $45 \mathrm{~mm}$ strips. To obtain biofilms of different ages on these strips, 3 replicates were placed inside a settlement sampler tube at sequential days, and hung under the wharf at the Portobello Marine Laboratory (Dunedin, New Zealand) at 2 to $3 \mathrm{~m}$ depth. Biofilm ages obtained were 22, 15, 8, 3, 2 and 0 d. Natural substrates were collected from the intertidal zone within Otago Harbour $24 \mathrm{~h}$ before the experiment was conducted. These included 3 replicates each of clean rock (not encrusted but with a biofilm), Corallinaencrusted rock, and left valves of the intertidal oyster Tiostrea chilensis. An attempt was made to obtain or manufacture substrates with a surface area of approximately $11.0 \mathrm{~cm}^{2}$.

On the day of the experiment, each substrate was laid flat on the bottom of a $125 \mathrm{ml}$ specimen jar containing $100 \mathrm{ml}$ of $1 \mu \mathrm{m}$ filtered seawater. Competent larvae were collected from cultures by removing the stirring paddles to allow ready-to-settle larvae to fall to the bottom of the beaker, and these were pipetted into a clean petri dish. Larvae from all 3 cultures were mixed in this dish and examined under a dissecting microscope. Twenty larvae with a well developed rudiment were randomly sampled and pipetted onto each of the substrates. At times of 0.5, 1 and $18 \mathrm{~h}$ after pipetting, each substrate container was examined under a dissecting microscope. Larvae at 1 of 3 different stages were counted: (1) swimming in the water column or crawling on the bottom; (2) motionless and attached by the tube feet to the substrate or bottom of the container but showing no indication of metamorphosis; and (3) metamorphosis, either in progress (indicated by retraction of the epithelium and protrusion of the larval calcite skeletal rods through the epithelial tissue (Cameron \& Hinegardner 1974), or complete, (indicated by loss of the skeletal rods and clear presence of a juvenile rudiment).

Univariate repeated measures analysis of variance (ANOVA) was used to test the effect of substrate type

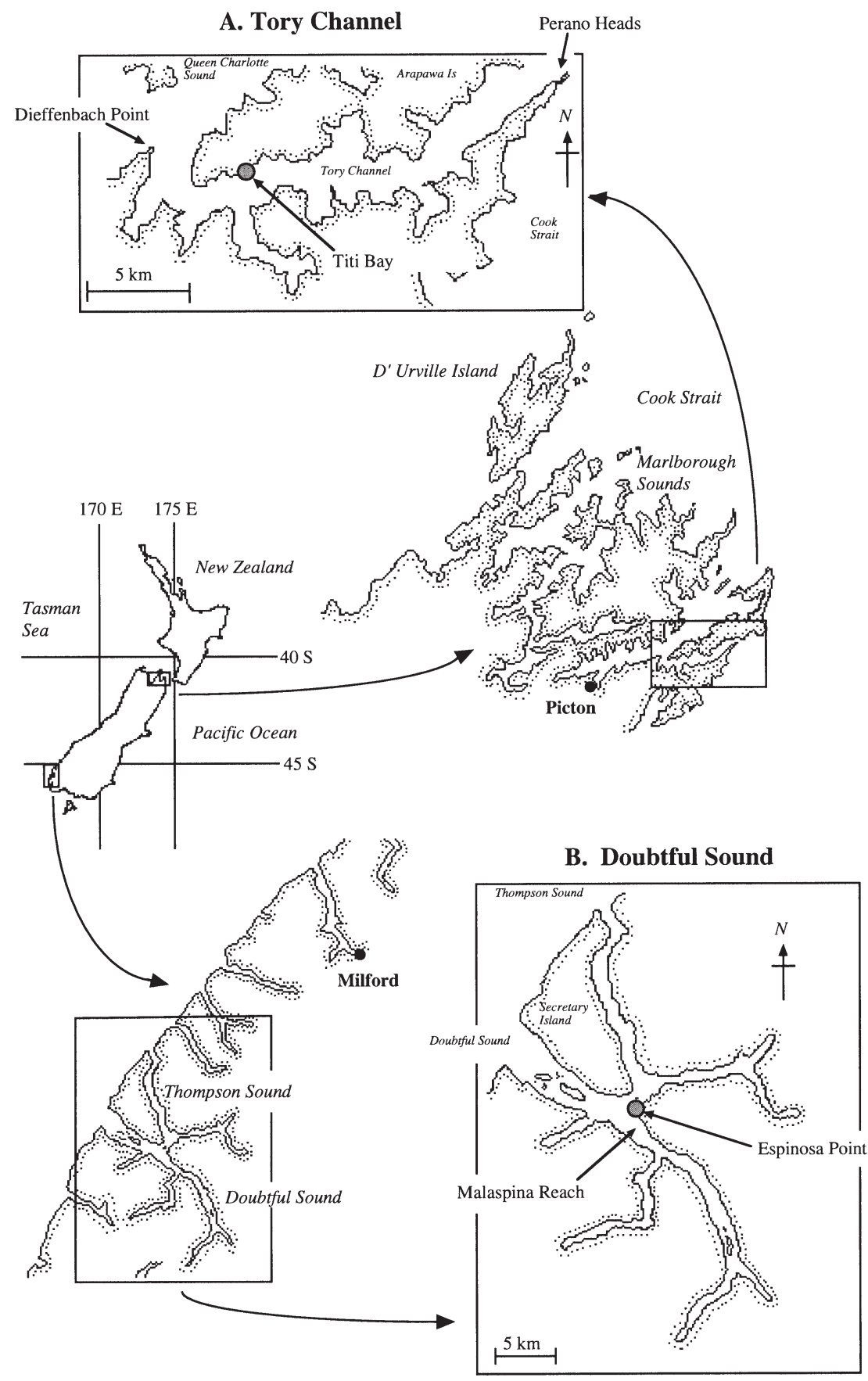

Fig. 1. Location of Titi Bay, Tory Channel (Fig. 1A) and Espinosa Point, Doubtful Sound (Fig. 1B). Indicated are the populations of Evechinus chloroticus where settlement and recruitment processes were examined $(\bullet)$ on both percentage settlement (larvae no longer swimming), and on percentage metamorphosis (larvae undergone or completing metamorphosis) at 0.5, 1 and $18 \mathrm{~h}$. Similarly, univariate repeated measures ANOVA was used to examine the relationship between age of biofilm and settlement/metamorphosis at 0.5, 1 and $18 \mathrm{~h}$ after exposure (although no metamorphosis was 
observed at $0.5 \mathrm{~h}$ ). To normalise percentages the dependent variables underwent angular transformation. Post-hoc pairwise multiple comparisons of settlement and metamorphosis were made using a Tukey's honest significance-differences (HSD) test $(=0.05)$.

Settlement sampler designs and testing. Three sea urchin settlement sampler designs were tested. The first, a 'pipe sampler', was based on the design of Harrold et al. (1991), and consisted of a PVC pipe (170 mm internal diameter, $185 \mathrm{~mm}$ length) containing 12 circular sheets of light diffuser panel. The sampler was kept pointing directly into the water current by having a stainless steel swivel at the attachment points, and a large vane $(100 \times 300 \mathrm{~mm})$ attached to the rear of the sampler. The second design, the 'brush sampler' was similar to those described by Ebert et al. (1994) and consisted of 2 commercial plastic scrubbing brushes $(55 \times 165 \mathrm{~mm})$ attached back-to-back so that the bristles (35 mm long) were pointing outward in opposite directions. Two holes were drilled through each end of the brush handles and nylon rope threaded to provide attachment points to an anchor and sub-surface buoy. The third design, the 'astroturf sampler' was based on a design described by Ebert et al. (1991) and consisted of a capped PVC pipe (110 mm diameter, $320 \mathrm{~mm}$ length), around which a sheet of commercial astroturf (5 mm think) was wrapped. The astroturf was kept in place by 3 cable ties. Nylon rope was threaded through holes drilled in each cap to provide attachment points to the anchor and sub-surface buoy. All samplers were anchored at a depth of $12 \mathrm{~m}$ below the surface (MLWN [Mean Low Water Neap]), and were maintained at $1.2 \mathrm{~m}$ above the seafloor by a sub-surface buoy.

Three replicates of each of the 3 settlement samplers were deployed at Espinosa Point, Doubtful Sound (Fig. 1B). These were serviced at 1 to 2 mo intervals over a period of 14 mo from 6 January 1992 to 18 March 1993 (although settlement only occurred between 23 August 1992 and 27 January 1993). The confounding effects of varying sampler deployment duration on biofilm age were assumed to be equal for each sampler design. On each servicing day, SCUBA divers carefully detached the samplers from the anchor and buoy and sealed them immediately in large plastic bags. The bagged samplers were placed in 201 buckets and returned to the surface. Old samplers were replaced with new ones at the same time. The retrieved samplers were transported back to the laboratory and all sea urchins anaesthetized and removed by adding $\mathrm{MgCl}_{2}$ at a concentration of $100 \mathrm{~g}$ per 1 of seawater within the plastic bags. After $1 \mathrm{~h}$ in $\mathrm{MgCl}_{2}$, all sea urchins were collected using a $200 \mu \mathrm{m}$ sieve and preserved in $70 \%$ ethyl alcohol. Samples were then sorted under a dissecting microscope and all sea urchins identified and test diameter (TD) measured using a calibrated ocular micrometer. Both newly settled Evechinus chloroticus and another echinoid species, Pseudechinus huttoni, were found on samplers. Identification of newly settled urchins was made early in the study by comparison with laboratory reared specimens of each species and by growing juvenile sea urchins removed from the samplers to a size of 2 to $3 \mathrm{~mm}$ TD, when pigmentation differences between species are apparent.

Statistical differences in the numbers of settlers on each design over the 3 sampling periods were tested using a log-linear model. Differences in the mean TD of newly settled Evechinus chloroticus among sampler designs were statistically tested using 1-way ANOVA of $\ln (x)$-transformed measurements for the 24 September to 27 November 1992 sampling period. Posthoc pairwise multiple comparisons of TD on each sampler design were made using Tukey's (HSD) test $(\alpha=0.05)$.

Spatial and temporal patterns of larval settlement. We define settlement here as the appearance of newly settled individuals on artificial samplers over a 1 to 2 mo interval. Pipe samplers were deployed at Espinosa Point, Doubtful Sound between 6 November 1991 and 30 November 1994 and at Titi Bay, Tory Channel between 19 November 1991 and 19 October 1994 (Fig. 1). At both sites, 3 replicate samplers were deployed at $12 \mathrm{~m}$ depth (1.2 $\mathrm{m}$ above the seafloor) and were serviced every 1 to 2 mo using methods described above. Deployment and recovery dates were kept as closely aligned as logistically possible at each site; the average deployment time was $42 \mathrm{~d}$ in Doubtful Sound and $45 \mathrm{~d}$ in Tory Channel. For each sampling period, the number of Evechinus chloroticus found on each sampler and their test diameter (TD) were recorded.

Recruitment. Population size structure and density: Sampling occurred on 8 occasions in Titi Bay, and on 7 occasions at Espinosa Point between 1992 and 1995. At both sites, sampling was undertaken within the same $100 \mathrm{~m}$ length of coastline. Due to differences in the habitat and distribution of Evechinus chloroticus between the 2 sites, 2 methods of sampling were required. For Tory Channel, a stratified sampling design was employed on each date, with a number of $1 \mathrm{~m}^{2}$ quadrats randomly sampled on transects positioned along the 3 , 6 and $9 \mathrm{~m}$ depth contours (MLWN). The number of quadrats sampled at each depth was usually 20, except on 5 March 1992 and 19 February 1995, when only 10 quadrats were sampled at each depth. For Doubtful Sound, 10 randomly placed $20 \mathrm{~m}$ transects were placed perpendicular to the shore and 20 contiguous $1 \mathrm{~m}^{2}$ quadrats were sampled down each transect from MLWN to a depth of approximately $15 \mathrm{~m}$. For both sites, 
all E. chloroticus found in the quadrats were counted and measured to the nearest $\mathrm{mm}$ using Vernier callipers. Semi-destructive sampling of the substrate was employed to measure cryptic individuals.

We define recruitment as the appearance of small individuals less than $20 \mathrm{~mm}$ TD $(<2 \mathrm{yr}$ age, Lamare \& Mladenov 2000) on natural substrates. It would have been better to quantify the number of 'young of the year' (Tegner \& Dayton 1981), namely individuals less than 8 to $10 \mathrm{~mm}$ TD (Lamare \& Mladenov 2000). These individuals are, however, difficult to sample in situ and might not be sampled in proportion to their true abundance (although see Rowley 1989). Due to the low numbers of recruits (particularly in Tory Channel) and differences in the total area sampled between sites, densities of recruits (<20 mm TD) were expressed as the number per $20 \mathrm{~m}^{2}$ transect. This method scales data to a fixed area, but will be biased if patterns of abundance at smaller scales $\left(60 \mathrm{~m}^{2}\right)$ are not the same as at larger scales $\left(200 \mathrm{~m}^{2}\right)$ over the range of areas sampled at the 2 sites. Patterns of abundance over different sampling areas were not examined, however the large area sampled at each site, and the large size of the sampling unit (20 $\mathrm{m}^{2}$ transects) may minimize the problem associated with different sample areas.

Statistical analysis. All statistical analyses noted were made using SAS/STAT ${ }^{\mathrm{TM}}$, Version 6 (SAS Institute Inc. 1987).

\section{RESULTS}

\section{Larval settlement behavior}

Substrate type

The percentage settlement of Evechinus chloroticus differed among substrate types and increased with time (Fig. 2A). Settlement was consistently higher on Corallina algae, with an average $58 \%$ settlement in this treatment after $0.5 \mathrm{~h}$, and $97 \%$ settlement after $1 \mathrm{~h}$. Lowest settlement occurred on plastic, reaching $58 \%$ by $18 \mathrm{~h}$. Repeated measures ANOVA of settlement on each substrate at the 3 exposure times (Table 1A) indicated significant differences in settlement between substrate type $(p=0.003)$ and between sampling times $(p<0.001)$, with no significant interaction between substrate and time $(p=0.088)$. Tukey's post-hoc comparisons indicated that settlement was significantly higher on natural substrates compared with plastic at 1 and $18 \mathrm{~h}(\mathrm{p} \leq 0.018)$, but there
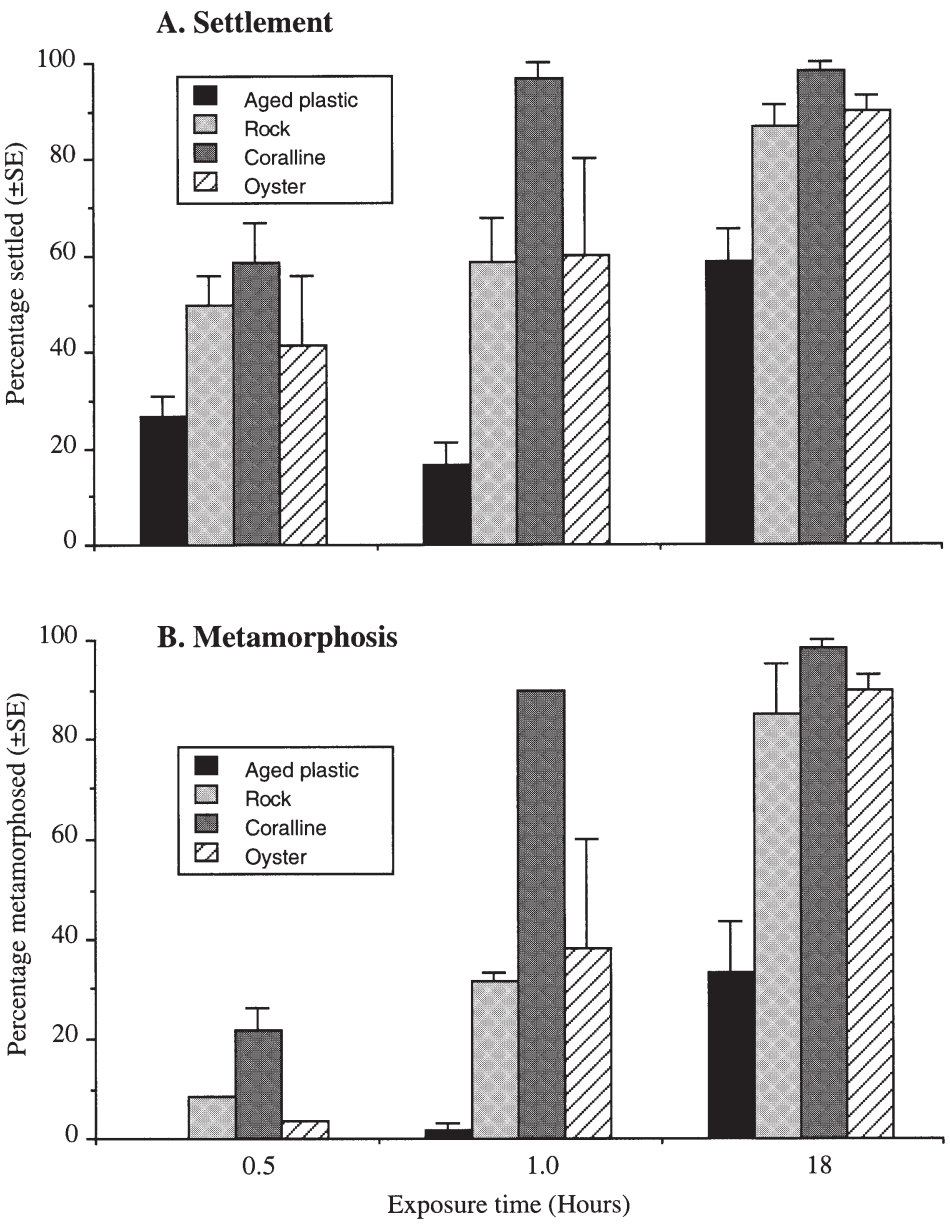

Fig. 2. Percentage settlement (A) and metamorphosis (B) of Evechinus chloroticus larvae on 4 substrates at 0.5, 1 and $18 \mathrm{~h}$ after the start of the experiment. $\mathrm{n}=3$ for each column

were no significant differences $(\mathrm{p} \leq 0.056)$ in percentage settlement among natural substrates.

Percentage metamorphosis increased over time in all treatments, and was consistently higher on the Corallina treatment, reaching an average $90 \%$ at $1 \mathrm{~h}$ (Fig. 2B). After $18 \mathrm{~h}$, metamorphosis on natural substrates varied from 85 to $98 \%$, but was only $33 \%$ on plastic. Repeated measures ANOVA (Table 1B) indicated that percentage metamorphosis of larvae differed significantly between substratum $(p<0.001)$ and between sampling time $(p<0.001)$, with no significant interaction between substrate and time $(p=0.077)$. Tukey's post-hoc comparisons indicate that metamorphosis was significantly higher on Corallina than other substrates at $0.5(p \leq 0.006)$ and $1 \mathrm{~h}(\mathrm{p} \leq 0.036)$, with no significant difference among the other substrates $(p \geq$ 0.078). At $18 \mathrm{~h}$, percentage metamorphosis was significantly higher on the natural substrates compared with the plastic ( $p \leq 0.001$ ), but not significantly different among natural substrates $(\mathrm{p} \geq 0.241)$. 
Table 1. Univariate repeated measures ANOVA of the percentage settlement (A) and metamorphosis (B) of competent Evechinus chloroticus larvae on 4 substrates. Repeated observations of settlement and metamorphosis were made at $0.5,1$ and $18 \mathrm{~h}$ after exposure. Percentages are angular transformed

\begin{tabular}{|c|c|c|c|c|c|}
\hline Source: & SS & Df & MS & $F$-ratio & p5 \\
\hline \multicolumn{6}{|l|}{ (A) Settlement } \\
\hline \multicolumn{6}{|l|}{ Between subjects } \\
\hline Substrate & 0.016 & 3 & 0.005 & 11.48 & 0.003 \\
\hline Error & 0.004 & 8 & 0.000 & & \\
\hline \multicolumn{6}{|l|}{ Within subject } \\
\hline Time & 0.012 & 2 & 0.006 & 26.72 & $<0.001$ \\
\hline Substrate $\times$ Time & 0.003 & 6 & 0.001 & 2.28 & 0.088 \\
\hline Error (Time) & 0.004 & 16 & 0.000 & & \\
\hline \multicolumn{6}{|c|}{ (B) Metamorphosis ${ }^{\mathrm{a}}$} \\
\hline \multicolumn{6}{|l|}{ Between subjects } \\
\hline Substrate & 0.025 & 3 & 0.008 & 22.61 & $<0.001$ \\
\hline Error & 0.003 & 8 & 0.000 & & \\
\hline \multicolumn{6}{|l|}{ Within subject } \\
\hline Time & 0.046 & 2 & 0.023 & 57.39 & $<0.001$ \\
\hline Substrate $\times$ Time & 0.007 & 6 & 0.001 & 2.99 & 0.077 \\
\hline Error (Time) & 0.006 & 16 & 0.000 & & \\
\hline \multicolumn{6}{|c|}{$\begin{array}{l}{ }^{a} \text { Within subject effects of Substrate } \times \text { Time violated the } \\
\text { assumption of sphericity (Mauchly's Sphericity test, } \mathrm{p}= \\
0.0258, \mathrm{Df}=2 \text { ). Therefore, degrees of freedom for calcu- } \\
\text { lating significant F-ratio were adjusted from } 6 \text { and } 16 \text { to } \\
3.64 \text { and } 9.71 \text { respectively using the Greenhouse-Geisser } \\
\text { estimator }(=0.607 \text { ) }\end{array}$} \\
\hline
\end{tabular}

Substrate biofilm age

Biofilm age affected the percentage settlement of Evechinus chloroticus larvae (Fig. 3A).Repeated measures ANOVA (Table 2A) indicated that percentage settlement increased significantly with increasing biofilm age $(p<0.001)$ and time of exposure $(p<$ 0.001 ), with no significant interaction between substrate and time $(\mathrm{p}=0.062)$. At $0.5 \mathrm{~h}$ exposure, settlement only occurred on substrates with an $8 \mathrm{~d}$ or older biofilm, with a significant increase in percentage settlement between 8 and $22 \mathrm{~d}$ biofilm $(p=0.006)$ and between 15 and 22 d biofilm ( $p=0.05)$. Settlement increased at $\sim 1.0 \%$ with every day increase in biofilm age. At $1 \mathrm{~h}$, settlement occurred on biofilm 3 days and older, with significantly more larvae settling on $22 \mathrm{~d}$ old than on $3 \mathrm{~d}$ old biofilm ( $\mathrm{p} \leq 0.027)$. At $18 \mathrm{~h}$, settlement increased $\sim 2.6 \%$ for every day of biofilm aging.

Metamorphosis of larvae did not occur in any of the treatments at $0.5 \mathrm{~h}$ exposure (Fig. 3B), and did not exceed an average $3.3 \%$ at $1 \mathrm{~h}$. At $18 \mathrm{~h}$, percentage metamorphosis increased at $\sim 1.8 \%$ per day of biofilm aging, reaching an average $41.6 \%$. Repeated measures ANOVA (Table 2B) indicated that percentage metamorphosis increased significantly with increasing biofilm age $(p=0.01)$ and time of exposure $(p=0.003)$.
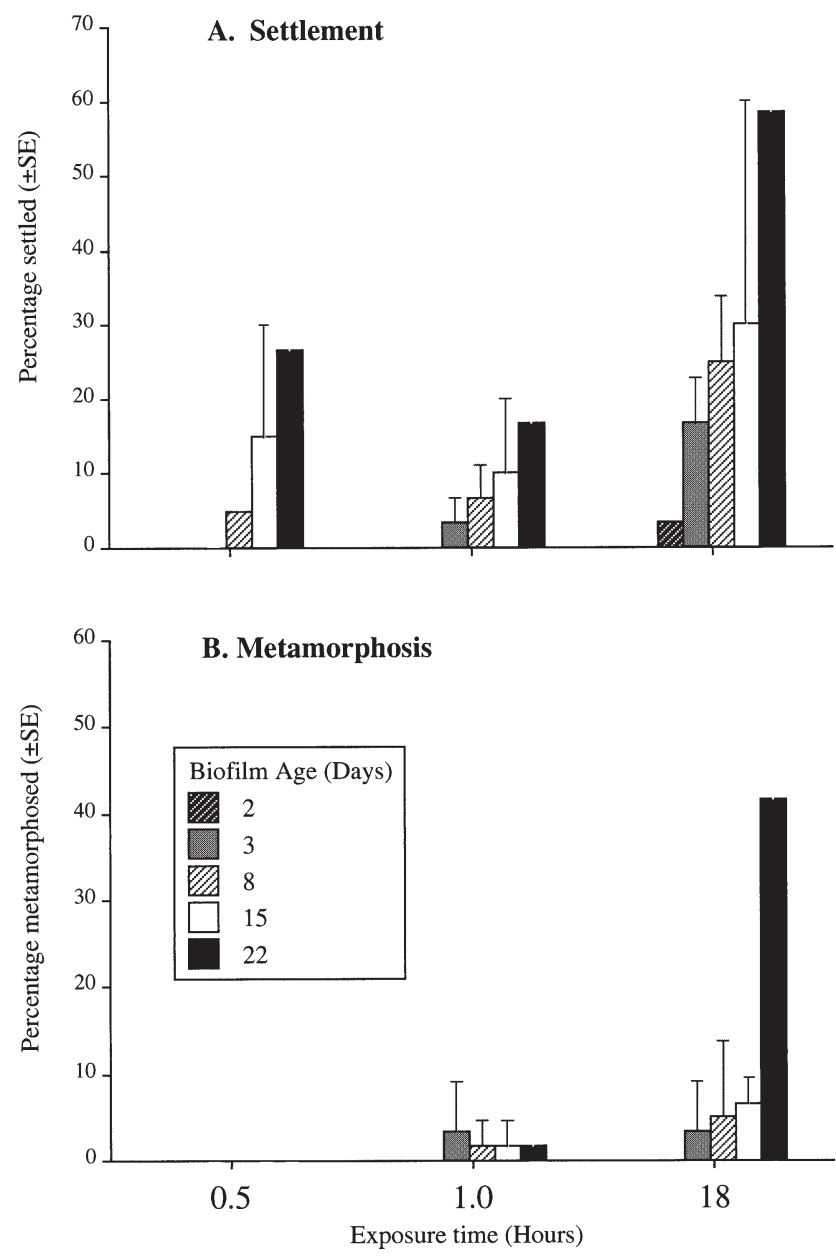

Fig. 3. Percentage settlement (A) and metamorphosis (B) of Evechinus chloroticus larvae versus biofilm age at 0.5, 1 and $18 \mathrm{~h}$ after the start of the experiment. $\mathrm{n}=3$ for each data point

There was a significant interaction of Substrate $\times$ Time $(p=0.018)$, indicating that the differences between percentage metamorphosis increased with exposure to the substrates (as indicated by much higher settlement on $22 \mathrm{~d}$ biofilm after $18 \mathrm{~h}$ ).

\section{Comparison of settlement sampler designs}

During the period that the 3 settlement samplers were tested, newly settled Evechinus chloroticus were recorded during 3 consecutive sampling periods from 23 August 1992 to 27 January 1993 (Fig. 4). The number of individuals recovered from the pipe samplers was found to be 3 - to 5 -fold higher than on the remaining designs. The log-linear model of number of settlers on each sampler design over the 3 periods indicated that numbers differed significantly between sampler types $\left(\chi_{2}^{2}=73.28, p<0.001\right)$ and between periods $\left(\chi_{2}^{2}=157.52, p<0.001\right)$. Settlement was significantly 
Table 2. Univariate repeated measures ANOVA of the percentage settlement (A) and metamorphosis (B) of competent Evechinus chloroticus larvae on substrates with biofilm ages of $0,2,3,8,15$ and $22 \mathrm{~d}$. Repeated observations of settlement and metamorphosis were made at $0.5,1$ and $18 \mathrm{~h}$ after exposure. Percentages are angular transformed

\begin{tabular}{|lccccc|}
\hline \multicolumn{1}{|c}{ Source: } & SS & Df & MS & F-ratio & p \\
\hline (A) Settlement & & & & & \\
Between subjects & & & & & \\
Biofilm & 1.488 & 5 & 0.298 & 21.111 & $<0.001$ \\
Error & 0.169 & 12 & 0.014 & & \\
Within subject & & & & & \\
Time & 0.478 & 2 & 0.239 & 22.896 & $<0.001$ \\
Biofilm $\times$ Time & 0.233 & 10 & 0.022 & 2.138 & 0.062 \\
Error (Time) & 0.251 & 24 & 0.010 & & \\
(B) Metamorphosis & & & & & \\
Between subjects & & & & & \\
Substrate & 0.274 & 5 & 0.055 & 5.03 & 0.010 \\
Error & 0.144 & 12 & 0.012 & & \\
Within subject & & & & & \\
Time & 0.090 & 1 & 0.090 & 13.56 & 0.003 \\
Substrate $\times$ Time & 0.218 & 5 & 0.044 & 4.27 & 0.018 \\
Error (Time) & 0.073 & 12 & 0.006 & & \\
\hline
\end{tabular}

higher during the middle sampling period than the remaining periods. The interaction term was not significant $\left(\chi_{4}^{2}=3.78, \mathrm{p}<0.4363\right)$.

The average TD of newly settled Evechinus chloroticus from the samplers over each period varied between sampler types and dates (Table 3). The largest mean TD (1.43 mm) was recorded for individuals recovered from the pipe samplers deployed between 24 September and 27 November 1992. Oneway ANOVA of the size of settlers recovered from each sampler design for this period indicated significant differences $\left(F_{(2,95)}=22.806, \mathrm{p}<0.001\right)$, with settlers from the pipe samplers significantly larger $(\mathrm{p}<0.01)$ than those from the brush or astroturf samplers.

Spatial and temporal patterns of

Evechinus chloroticus settlement

Patterns of settlement on pipe samplers during 1992, 1993 and 1994 are illustrated for Tory Channel and Doubtful Sound (Fig. 5). In Tory Channel (Fig. 5A), settlement was restricted to February to April. Settlement for any one sampling period varied interannually from an average of 0.54 settlers per sampler $\mathrm{d}^{-1}$ (15 February 1993 to 7 March 1993) to no settlement (1994). The settlement period in 1992 occurred within a $37 \mathrm{~d}$ period and within a $51 \mathrm{~d}$ period in 1993. The

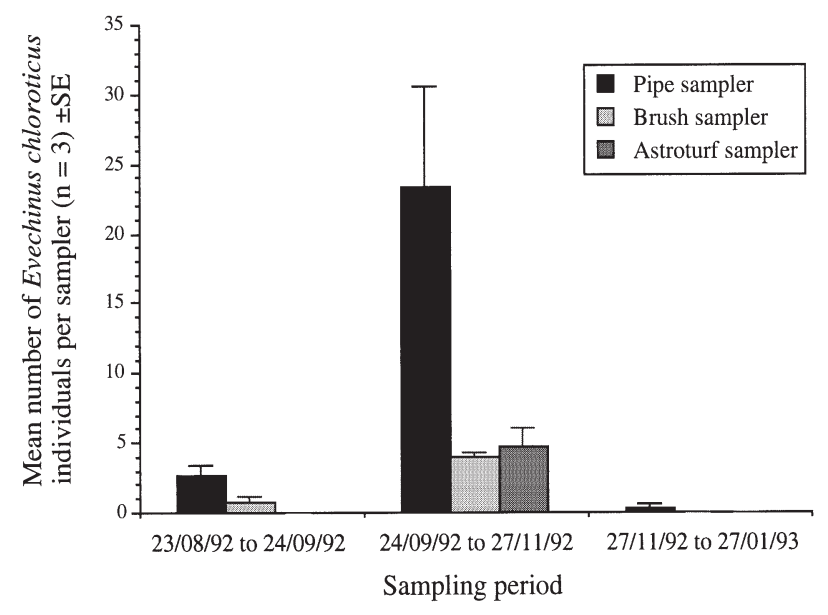

Fig. 4. Mean number of newly settled Evechinus chloroticus recovered from 3 settlement sampler designs deployed in Doubtful Sound from 23 August 1992 to 27 January 1993. $\mathrm{n}=3$ for each column

greatest total number of Evechinus chloroticus recovered (39) was in 1993.

In Doubtful Sound (Fig. 5B), settlement occurred over a longer period than in Tory Channel, with newly settled individuals recovered from the samplers from August to January in 1992 to 1993 and August to March in 1993 to 1994. Settlement rate within a sampling period ranged from an average of 1.14 settlers per sampler day ${ }^{-1}$ (27 September to 27 November 1992/93) to no settlement (1994/95 settlement period). The total number of individuals recovered was greatest (79) in 1992/93.

\section{Size range of individual settlers}

The average TD of urchins recovered on each sampling date ranged from 0.41 to $0.52 \mathrm{~mm}$ in Tory Channel and from 0.49 to $1.43 \mathrm{~mm}$ in Doubtful Sound (Table 4). On all dates, the mean size of individuals recovered from the samplers was greater than the mean size of newly settled individuals observed in the laboratory ( $0.37 \mathrm{~mm}$ TD). At both sites, the size distribution of individuals recovered from the samplers on each date was uni-modal and within a very small size
Table 3. Mean test diameter $(\mathrm{mm}) \pm \mathrm{SE}$ of Evechinus chloroticus recovered from each of the settlement sampler design deployed between 23 August 1992 and 27 January 1993. $n=$ total number recovered from each sampler design

\begin{tabular}{|lccc|}
\hline \multicolumn{1}{|c|}{ Date: } & Aug/Sep 92 (n) & Oct/Nov 92 (n) & Dec 92/Jan 93 (n) \\
\hline Pipe sampler & $0.65 \pm 0.05(8)$ & $1.43 \pm 0.19(70)$ & $0.63(1)$ \\
Brush sampler & $0.71 \pm 0.08(2)$ & $0.93 \pm 0.05(12)$ & \\
Astroturf sampler & & $1.02 \pm 0.15(14)$ & \\
\hline
\end{tabular}



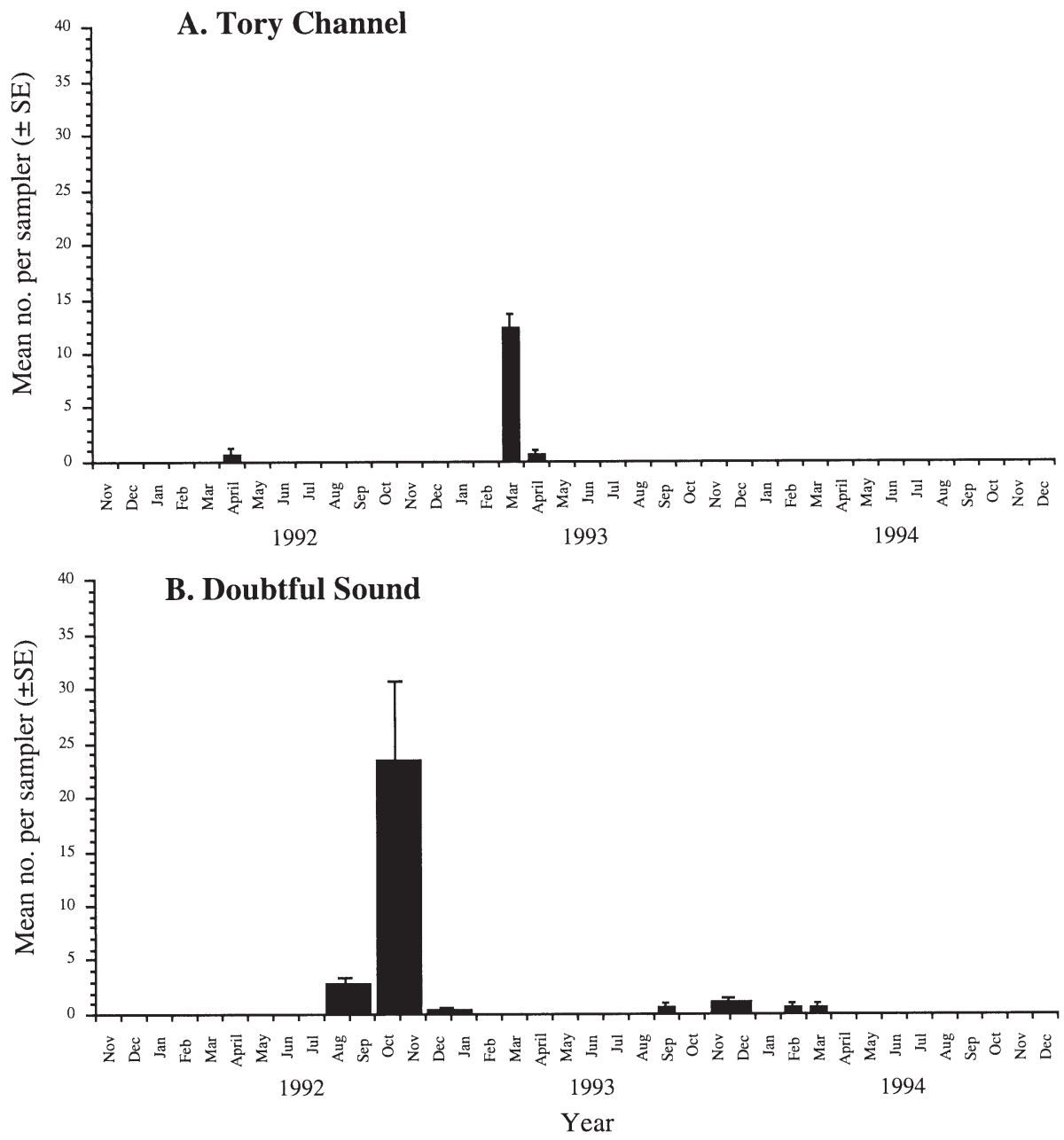

Fig. 5. Mean number of newly settled Evechinus chloroticus recovered from pipe samplers deployed in Tory Channel (A) and Doubtful Sound (B) at 1 to 2 mo intervals during 1992, 1993 and 1994. $\mathrm{n}=3$ for each column

range. An exception was for settlers recovered from Doubtful Sound between 24 September and 27 November 1992, when size ranged from 0.58 to $2.48 \mathrm{~mm}$.

\section{Recruitment}

Population size structure and density

Size-frequency distributions are given for the Tory Channel (Fig. 6) and Doubtful Sound (Fig. 7) populations for each sampling date. In Tory Channel, the population size-frequency distribution was unimodal and dominated by large individuals, with only a small proportion of the population consisting of recruits. In contrast, individual size-frequency distributions in Doubtful Sound were polymodal, with the mode of adults making up a relatively small proportion. A higher proportion of recruits (0 to $20 \mathrm{~mm}$ TD) occurred in Doubtful Sound.
In Tory Channel, the mean density of all urchins $20 \mathrm{~m}^{-2}$ ranged from 112.7 to 183.3 with no consistent trend of increasing or decreasing numbers over the sampling period (Table 5A). The mean density of all urchins $20 \mathrm{~m}^{-2}$ transect was an order of magnitude lower in Doubtful Sound (Table 5B), ranging from 12.3 to 41.1 per $20 \mathrm{~m}^{2}$, with the density of individuals increasing over the 3 year sampling period. The number of recruits $(<20 \mathrm{~mm}$ TD) $20 \mathrm{~m}^{-2}$ was higher in Doubtful Sound compared with Tory Channel over the period of sampling. For Doubtful Sound (Table 5B), densities ranged from 0.6 to 13.8 sea urchins $20 \mathrm{~m}^{-2}$ (mean $=5.0$ ). Densities varied 23-fold over the 33 mo sampling period, with maximum densities occurring on $17 \mathrm{Au}-$ gust 1993. Densities of recruits in Tory Channel ranged from 0.0 to 5.0 per $20 \mathrm{~m}^{2}$ (mean $=1.4$ ), with densities increasing to a maximum on 16 September 1993 (Table 5A).

The percentage of sea urchins less than $20 \mathrm{~mm}$ TD at each site (Table 5) was lower in the Tory Channel population $($ mean = $0.89 \%)$, compared with Doubtful Sound (mean $=9.27 \%$ ) over the sampling period. For Tory Channel, the percentage ranged from 0 to $3.55 \%$ of the total population while the percentage in Doubtful Sound ranged from 2.31 to $27.59 \%$. In Doubtful Sound, the proportion of juveniles in the population increased 10-fold in the first year of sampling, reaching a maximum of $27.59 \%$ on 18 March 1993. This was followed by a steady decrease to $2.31 \%$ by 30 November 1994 , almost identical to the proportion found in the initial survey.

\section{Settlers and recruitment of Evechinus chloroticus juveniles}

Using pipe samplers, settlement of Evechinus chloroticus during the $3 \mathrm{yr}$ can be correlated with subsequent changes in recruit abundance in the adjacent sea urchin population. For Doubtful Sound, the large settlement between August 1992 and January 1993 
Table 4. Mean test diameter of Evechinus chloroticus recovered from pipe samplers deployed in Tory Channel (A) and Doubtful Sound (B) during 1992, 1993 and 1994

\begin{tabular}{|lrccc|}
\hline $\begin{array}{l}\text { Sampling period } \\
\text { (days) }\end{array}$ & $\begin{array}{c}\text { Sample } \\
\text { duration }\end{array}$ & $\begin{array}{c}\text { No. of urchins } \\
\text { recovered }\end{array}$ & $\begin{array}{c}\text { Mean test } \\
\text { diameter (mm) }\end{array}$ & SE \\
\hline $\begin{array}{l}\text { (A) Tory Channel } \\
\text { 5 Mar to 11 Apr 1992 }\end{array}$ & 37 & 2 & 0.48 & 0.05 \\
15 Feb to 7 Mar 1993 & 51 & 37 & 0.41 & 0.03 \\
7 Mar to 7 Apr 1993 & 31 & 2 & 0.52 & 0.04 \\
Newly settled (laboratory) & 0 & 5 & 0.37 & \\
(B) Doubtful Sound & & & & \\
23 Aug to 24 Sep 1992 & 63 & 8 & 0.67 & 0.05 \\
24 Sep to 27 Nov 1992 & 61 & 70 & 1.43 & 0.18 \\
27 Nov to 27 Jan 1993 & 61 & 1 & 0.63 & - \\
18 Aug to 29 Sep 1993 & 42 & 2 & 0.59 & 0.01 \\
28 Oct to 3 Dec 1993 & 34 & 4 & 0.58 & 0.02 \\
3 Feb to 4 Mar 1994 & 30 & 2 & 0.49 & 0.05 \\
4 Mar to 21 Mar 1994 & 48 & 3 & 0.67 & 0.03 \\
Newly settled (laboratory) & 0 & 5 & 0.37 & \\
\hline
\end{tabular}

was followed by an increase in the density of juveniles from 2.1 to 13.8 individuals $20 \mathrm{~m}^{-2}$ over the next 9 mo. Settlement during the following $2 \mathrm{yr}$ was comparatively low, during which time the density of recruits decreased from 13.8 to 2.1 sea urchins $20 \mathrm{~m}^{-2}$. A similar pattern is evident in Tory Channel where a small rate of settlement was observed in 1992 and the density of recruits over the following year was less than 0.6 sea urchins $20 \mathrm{~m}^{-2}$. In 1993 in Tory Channel, settlement was higher than in the previous year and the subsequent density of recruits increased from 0.3 to 5.0 sea urchins $20 \mathrm{~m}^{-2}$ in the following $5 \mathrm{mo}$. No settlement was detected in 1994, although the density of juveniles increased from 0.3 to 3.3 sea urchins $20 \mathrm{~m}^{-2}$. The relationship between settlement intensity on the samplers and subsequent juvenile densities was quantified by plotting the total number of settlers recovered over a given settlement period, with maximum juvenile density for the following period until the next period of settlement (Fig. 8). While based on a very few data, there is a significant linear relationship between settlement on samplers and subsequent juvenile density $\left(F_{(1,4)}=\right.$ 28.07, $\mathrm{p}=0.013, \mathrm{R}^{2}=0.903$ ).

\section{DISCUSSION}

\section{Settlement and metamorphosis behavior of Evechinus chloroticus larvae}

To assess the effects of competent larval behavior on the observed patterns of recruitment, settlement and metamorphosis in this species were examined. Evechinus chloroticus larvae showed selective settlement in the laboratory, consistent with findings of selective settlement of Strongylocentrotus droebachiensis (Pearce \& Scheibling 1990, 1991), S. purpuratus (Rowley 1989) and Holopneustes purpurascens (Williamson et al. 2000) larvae. Settlement behavior of E. chloroticus in the laboratory suggests that settlement rate on samplers deployed in the field will be significantly less than $100 \%$. Firstly, settlement approached $100 \%$ on $\mathrm{Co}$ ralline algae $(97 \%)$, but was significantly less on the artificial substrates used in the settlement samplers (58\%). Second, settlement was correlated with age of biofilm, increasing linearly by $\sim 2.6 \%$ for every day of aging. Extrapolating the laboratory data to settlement on samplers suggests settlement will occur only after the samplers have been in the water for at least $2 \mathrm{~d}$, and may be in the order of $\sim 58 \%$ after $22 \mathrm{~d}$ aging. Average length of time samplers were deployed in the field was 42 and $45 \mathrm{~d}$ in Doubtful Sound and Tory Channel, respectively (i.e. a mean biofilm age of 21 and $22.5 \mathrm{~d}$ ) which would equate to a mean settlement rate of the order of $\sim 58 \%$. This suggests that settlement on the samplers may be only half the rate of settlement of larvae on the surrounding natural substrates (which approached $100 \%$ in the laboratory). Metamorphosis rates follow a similar trend, approaching $100 \%$ on Coralline algae but only reaching $41 \%$ for the aged plastic. Metamorphosis rates increased $1.8 \%$ for every day of aging which would equate to a mean metamorphosis rate on the samplers in the order of $40 \%$. Furthermore, given the positive correlation between settlement rate and biofilm age, the timing of the arrival of larvae and sampler deployment are also likely to have a significant influence on settlement and metamorphosis rate.

\section{Growth of newly settled Evechinus chloroticus on samplers}

The mean TD of individuals recovered from the pipe samplers ranged between 0.41 and $0.52 \mathrm{~mm}$ in Tory Channel and between 0.49 and $1.43 \mathrm{~mm}$ in Doubtful Sound over the $3 \mathrm{yr}$ sampling period. These are significantly larger than the size of newly settled Evechinus chloroticus ( $0.37 \mathrm{~mm}$ TD) measured in the laboratory immediately after settlement. After $21 \mathrm{~d}$ in Doubtful Sound, the mean size of new settlers on a natural substrate was $0.649 \mathrm{~mm}$ (M.F.B. unpubl. data). This is close to the size of Tory Channel settlers and substantially less than those from samplers in Doubtful Sound 


\section{Tory Channel}
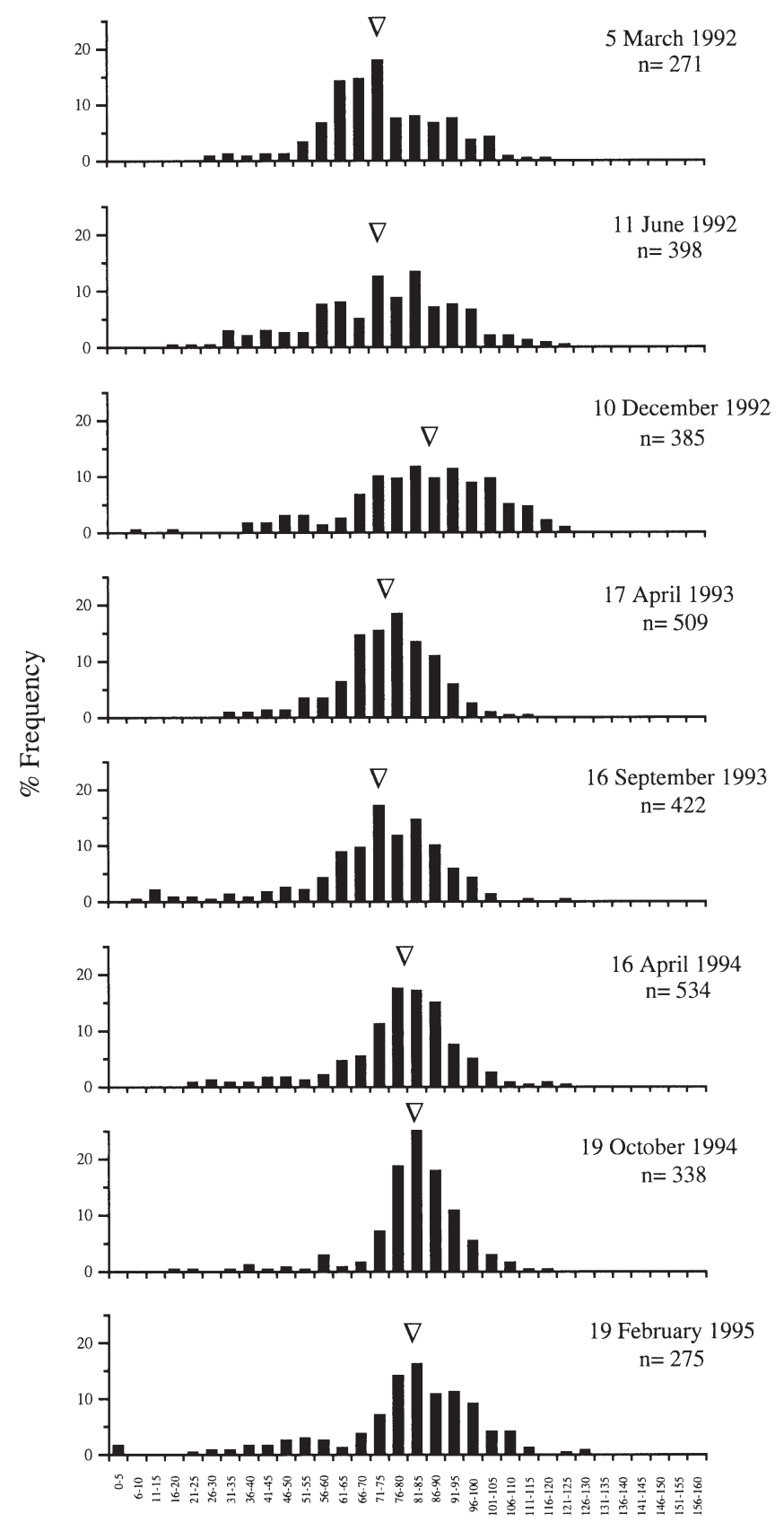

Size Class (mm)

Fig. 6. Size-frequency distributions of Evechinus chloroticus individuals sampled from Titi Bay, Tory Channel between 5 March 1992 and 19 February 1995. The mean test diameter of each sample are indicated $(\nabla) . \mathrm{n}=$ number of urchins in each sample

(although these samplers were deployed for up to $61 \mathrm{~d})$. The mean size of individuals recovered from the pipe samplers $(1.43 \mathrm{~mm})$ on 27 November 1992 was also significantly larger than that of juveniles recov-

\section{Doubtful Sound}
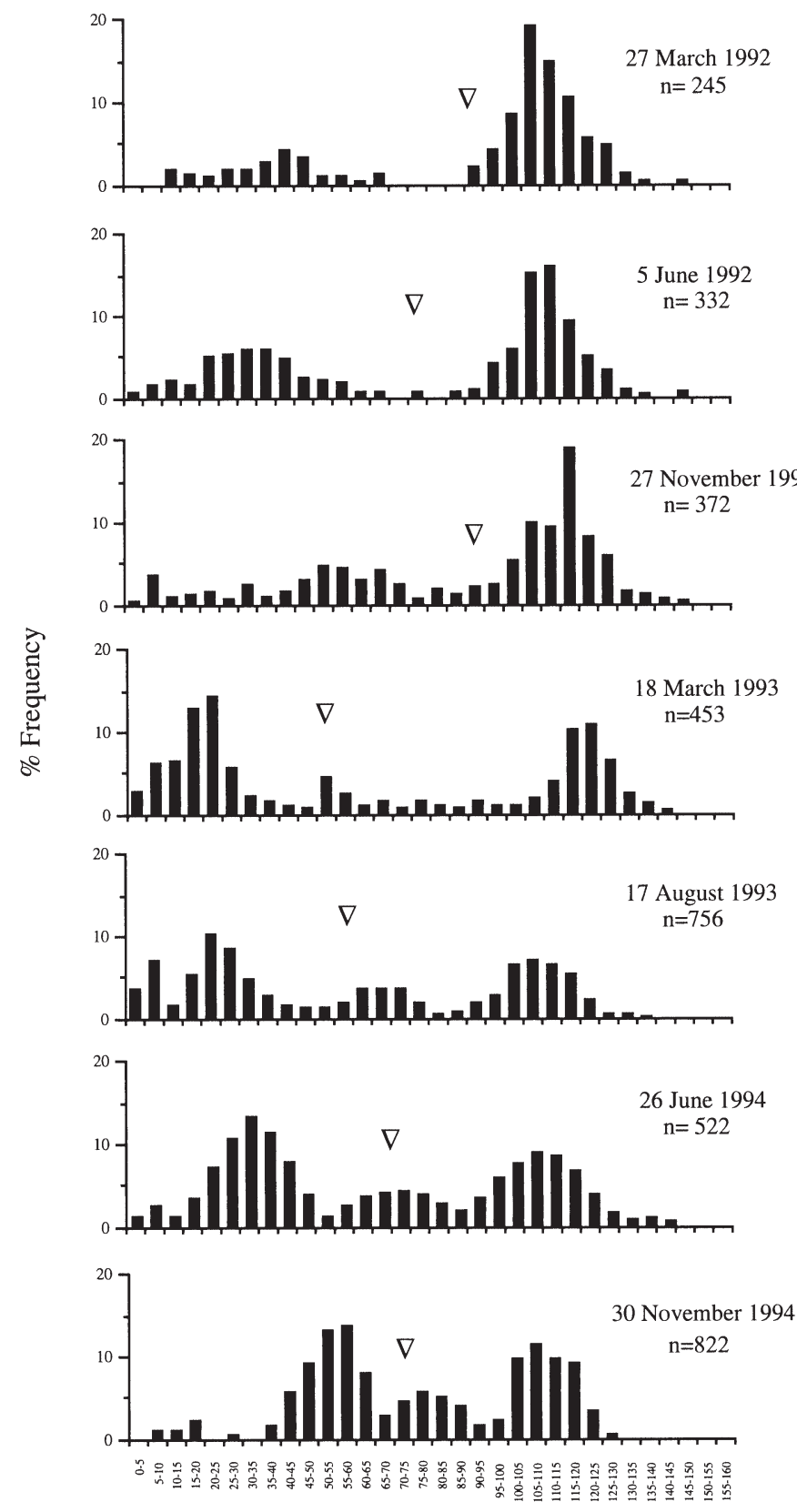

Size Class (mm)

Fig. 7. Size-frequency distributions of Evechinus chloroticus individuals sampled from Espinosa Point, Doubtful Sound between 27 March 1992 and 30 November 1994. The mean test diameter of each sample are indicated $(\nabla) . n=$ number of urchins in each sample

ered from either the brush $(0.93 \mathrm{~mm})$ or astroturf samplers $(1.02 \mathrm{~mm})$. Our findings suggest that there was sufficient food for E. chloroticus to grow on the samplers, particularly on the pipe samplers. Newly settled 
Table 5. Total area sampled, total number of Evechinus chloroticus, mean density of sea urchins $20 \mathrm{~m}^{-2}$ transect, and mean density of juveniles (<20 mm TD) $20 \mathrm{~m}^{-2}$ transect in Tory Channel (A) and in Doubtful Sound (B)

\begin{tabular}{|c|c|c|c|c|c|}
\hline Sampling date & $\begin{array}{c}\text { Total area } \\
\text { sampled }\left(\mathrm{m}^{2}\right)\end{array}$ & $\begin{array}{l}\text { Total number } \\
\text { sampled }\end{array}$ & $\begin{array}{l}\text { Mean density } \\
20 \mathrm{~m}^{-2} \text { (SD) }\end{array}$ & $\begin{array}{l}\text { Mean density of recruits } \\
\left(<20 \mathrm{~mm} \text { TD) } 20 \mathrm{~m}^{-2} \text { (SD) }\right.\end{array}$ & $\begin{array}{c}\% \text { of } \\
\text { population }\end{array}$ \\
\hline \multicolumn{6}{|c|}{ (A) Tory Channel recruits } \\
\hline 5 Mar 1992 & 30 & 271 & $180.7(120.08)$ & $0.0(0.0)$ & 0.00 \\
\hline 11 Jun 1992 & 60 & 398 & $132.7(132.7)$ & $0.3(0.6)$ & 0.25 \\
\hline 10 Dec 1992 & 60 & 385 & $128.3(142.94)$ & $0.7(0.6)$ & 0.52 \\
\hline 17 Apr 1993 & 60 & 509 & $169.7(165.64)$ & $0.3(0.6)$ & 0.19 \\
\hline 16 Sep 1993 & 60 & 422 & $140.7(149.94)$ & $5.0(5.0)$ & 3.56 \\
\hline 16 Apr 1994 & 60 & 534 & $178.0(158.54)$ & $1.0(2.0)$ & 0.56 \\
\hline 19 Oct 1994 & 60 & 338 & $112.7(186.7)$ & $0.3(0.6)$ & 0.29 \\
\hline 19 Feb 1995 & 30 & 275 & $183.3(99.74)$ & $3.3(3.4)$ & 1.82 \\
\hline Mean & & & 153.3 & 1.4 & 0.89 \\
\hline \multicolumn{6}{|c|}{ (B) Doubtful Sound recruits } \\
\hline 27 Mar 1992 & 200 & 245 & $12.3(6.7)$ & $0.6(0.8)$ & 2.45 \\
\hline 5 Jun 1992 & 200 & 332 & $16.6(5.58)$ & $0.9(1.0)$ & 2.71 \\
\hline 27 Nov 1992 & 200 & 372 & $18.6(4.98)$ & $2.1(7.0)$ & 5.64 \\
\hline 18 Mar 1993 & 200 & 453 & $22.7(8.58)$ & $12.5(7.0)$ & 27.59 \\
\hline 17 Aug 1993 & 200 & 756 & $37.8(12.02)$ & $13.8(8.2)$ & 18.25 \\
\hline 26 Jun 1994 & 200 & 522 & $26.1(15.04)$ & $3.1(3.2)$ & 5.94 \\
\hline 30 Nov 1994 & 200 & 822 & $41.1(8.64)$ & $2.1(3.0)$ & 2.31 \\
\hline Mean & & & 25.0 & 5.0 & 9.27 \\
\hline
\end{tabular}

Strongylocentrotus franciscanus and $S$. purpuratus commence feeding at $9 \mathrm{~d}$ (Miller \& Emlet 1999). Newly settled E. chloroticus normally feed on microbial surface films, filamentous algae and crustose Coralline algae for the first 150 to 200 d (Lamare \& Mladenov 2000). Both a microbial surface film and filamentous algae were present on the samplers after deployment in the field.

\section{Recruitment processes in Evechinus chloroticus}

The estimates of settlement and metamorphosis on artificial substrates suggest that the samplers greatly underestimate larval supply at each site. The findings of the present study are probably further confounded by high and unmeasured post-settlement mortality of newly settled Evechinus chloroticus on the samplers, particularly due to average time of the deployment period (mean 42 to $45 \mathrm{~d}$ ). Despite these, settlement into the samplers and recruitment could be correlated, and settlement samplers can provide insight into the recruitment processes of E. chloroticus. Furthermore, if the degree of underestimation does not significantly change spatially or temporally, then the settlement samplers provide a useful relative measure of settlement between sites and years.

A high degree of inter-annual variability in settlement occurred in both populations. While both the Doubtful Sound and Tory Channel populations experienced settlement in 2 of the 3 sampling yr, settlement

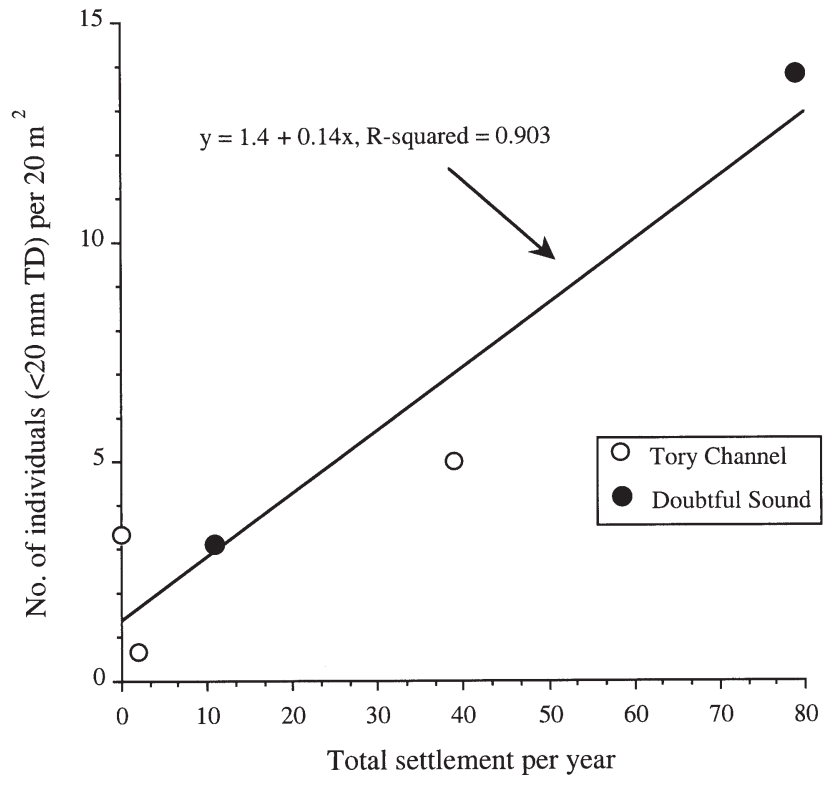

Fig. 8. Relationship between settlement and annual recruitment of Evechinus chloroticus for the Tory Channel and Doubtful Sound populations. Settlement is expressed as the total number of newly settled urchins recovered from the settlement samplers for the settlement season. Annual recruitment is expressed as the maximum number of sea urchins $(<20 \mathrm{~mm}$ TD) $20 \mathrm{~m}^{-2}$ for the post-settlement period. The linear relationship $(y=1.4+0.14 x)$ is expressed for both sites pooled

was greater in Doubtful Sound. The number of settled Evechinus chloroticus recovered from the samplers in Doubtful Sound over the 3 yr period was double that of 
Tory Channel. In addition, a longer settlement period existed in Doubtful Sound ( 5 to 6 mo) compared with Tory Channel ( 1 to $2 \mathrm{mo}$ ).

Variability in recruitment has been attributed to variability in gamete production (Guillou \& Michel 1993), larval feeding history (Basch \& Pearse 1996), larval growth and mortality (Foreman 1977, Tegner \& Dayton 1981, Hart \& Scheibling 1988) and larval transport (Cameron \& Rumrill 1982, Emlet 1986, Ebert et al. 1994). In Evechinus chloroticus, annual variability in reproduction is low, both in the Tory Channel populations (Brewin et al. 2000) and Doubtful Sound (Lamare 1997), and larval transport, growth and mortality are probably more important pre-settlement processes. Transport of E. chloroticus larvae in Doubtful Sound (Lamare 1998), and genetic differentiation of E. chloroticus throughout New Zealand (Mladenov et al. 1997) indicate that Doubtful Sound is a closed or semi-closed population in terms of larval dispersion. Restricted water movement into and out of Doubtful Sound means that larvae originating in the fiord may be retained and can eventually recruit within the fiord. This contrasts with the majority of open coast populations of E. chloroticus, which show no genetic differentiation and are almost certainly open populations. Tory Channel is an open channel that has extremely high flows and rates of water exchange; E. chloroticus populations here are also likely to have open recruitment. Open marine invertebrate populations are more likely to have low or variable recruitment primarily due to a decoupling of reproduction and recruitment (Hughes 1990), and to the variability of larvae supply associated with long range larval transport (Vance 1980, 1984).

Given these findings it is interesting to note that while settlement and recruitment were greater in Doubtful Sound during the study period, population density was a magnitude higher in Tory Channel. One explanation is that the greater population density in Tory Channel may reflect higher historical recruitment rates in this population, and/or recent recruitment failure in Doubtful Sound prior to the current research. The population structures in conjunction with estimates of growth rates in both populations (Lamare \& Mladenov 2000) provide some insight into recruitment history. Growth of Evechinus chloroticus in Tory Channel slows and approaches an asymptote at a test diameter of $\sim 86 \mathrm{~mm}$. The largest numbers were in these size classes, and reflects a stable size structure (Fig. 6) where there is an accumulation of large individuals as growth slows and a recent history of low 'trickle' recruitment. Changes in the size structure of the Doubtful Sound population over the course of the study indicate previous recruitment failure. Growth of sea urchins in Doubtful Sound approaches an asymptote of $\sim 104 \mathrm{~mm}$ TD (Lamare \& Mladenov 2000) and the size structure reflects an accumulation of individuals in the largest size classes. A bimodal distribution existed at the commencement of population sampling, characterized by an absence of sea urchins between 75 and $90 \mathrm{~mm}$ TD. These size classes were later filled by the growth of smaller individuals, indicating a period of poor recruitment in the past (estimated from the growth studies to occur 1985 to 1986). An increase in population density in Doubtful Sound over the course of the investigation from 12.3 to 41.1 sea urchin $20 \mathrm{~m}^{-2}$ was due to the large recruitment in 1992, further suggesting a population size that was limited by previous recruitment failure.

An alternative explanation or contributing factor would be a lower rate of post-settlement mortality in Tory Channel, which would result in higher population densities at this site. Estimates of mortality using a size-structured model (Ebert 1973, 1987) have been made for both populations of Evechinus chloroticus (Lamare 1997). This modelling suggested instantaneous mortality was lower in Tory Channel $(5.01 \%$ $\mathrm{yr}^{-1}$ ) than Doubtful Sound $\left(9.27 \% \mathrm{yr}^{-1}\right)$, consistent with observed differences population densities.

Spatial and temporal differences in settlement were closely coupled with recruitment patterns of Evechinus chloroticus in Tory Channel and Doubtful Sound. During 1992, 1993 and 1994 both settlement and recruitment of E. chloroticus were higher in Doubtful Sound than in Tory Channel. The greater settlement in Doubtful Sound coincides with both higher recruit densities, and a higher proportion of the population made up of recruits. These results strongly suggest that recruitment processes in E. chloroticus are governed by supply-side ecology, a finding consistent with many marine populations, but with direct implications for the longterm conservation of $E$. chloroticus populations.

\section{CONCLUSIONS}

An apparent relationship between settlement and recruitment has several potential applications for the management of Evechinus chloroticus. Samplers can be used to identify relative spatial and temporal differences in settlement intensity and may predict subsequent patterns of recruitment, identify populations that have consistently poor recruitment and therefore greater vulnerability to overfishing, and identify years of good or poor recruitment. A good example of this was found in the present study. The large settlement detected on the pipe samplers in Doubtful Sound between August 1992 and January 1993 was correlated with a 10.9-fold increase in the juvenile density in the adjacent population. Over the following $3 \mathrm{yr}$, this cohort grew to a mean size of $51.1 \mathrm{~mm}$ TD and by 30 November 1994 made up $\sim 31 \%$ of the population. 
Commercial fisheries first target $E$. chloroticus at a size of $50 \mathrm{~mm}$ (McShane et al. 1994). Therefore, large settlement events on samplers may be used to predict a future increase in the size of the stocks. Periods of poor recruitment and future decreases in stock size could be indicated by low settlement on the samplers (as appeared to occur in Doubtful Sound in 1994). In terms of managing an E. chloroticus metapopulation, settlement samplers (perhaps used in conjunction with an examination of gonad production) could be used to identify potential source (those with a high reproductive output but low input of larvae) and sink populations. By identifying source and sink populations, stratified fishing practices could be employed to conserve source populations.

Acknowledgements. Thanks to Paul Meredith, Clive Heseltine, Paul Brewin, Paul Jones, Donald Huntly, Franz Smith, and Alan Perano for technical assistance. Steve Wing provided valuable insight and discussion of recruitment processes and metapopulation dynamics in marine species. This paper also benefited from comments from David Fletcher, Philip Mladenov, Rachel Berquist, Jeb Byers, Brian Stewart, Brian Niven, and 3 anonymous reviewers. Research was funded by an Otago Research Grant provided by the University of Otago (New Zealand), and was generously supported by Fiordland Travel Limited (NZ).

\section{LITERATURE CITED}

Basch LV, Pearse JS (1996) Consequences of larval feeding environment for settlement and metamorphosis of a temperate echinoderm. Oceanol Acta 19(3-4):273-285

Brewin PE, Lamare MD, Keogh JA, Mladenov PV (2000) Reproductive variability over a four-year period in the sea urchin Evechinus chloroticus (Echinoidea: Echinodermata) from differing habitats in New Zealand. Mar Biol 137:543-557

Butman CA (1987) Larval settlement on soft-sediment invertebrates: the spatial scales of pattern explained by active habitat selection and the emerging role of hydrodynamical processes. Oceanogr Mar Biol Annu Rev Ecol Syst 25: 113-165

Cameron RA, Hinegardner RT (1974) Initiation of metamorphosis in laboratory cultured sea urchins. Biol Bull 146 335-342

Cameron RA, Rumrill SS (1982) Larval abundance and recruitment of the sand dollar Dendraster excentricus in Monterey Bay, California, USA. Mar Biol 71:197-202

Ebert TA (1973) Estimating growth and mortality rates from size data. Oecologia 11:281-298

Ebert TA (1987) Estimating growth and survival parameters by non-linear regression using average size in catches. In: Pauly D, Morgan GR (ed.) Theory and application of length-based methods in fisheries research. International Centre for Living Aquatic Resources Management Conference proceedings, Manila 13, p 35-44

Ebert TA, Schroeter SC, Dixon JD (1991) Studies on the feasibility of sea urchin enhancement in California. Technical Report, No. FG9310

Ebert TA, Schroeter SC, Dixon JD, Kalvass P (1994) Settlement patterns of red and purple sea urchins (Strongylo- centrotus franciscanus and $S$. purpuratus) in California, USA. Mar Ecol Prog Ser 111:41-52

Emlet RB (1986) Larval production, dispersal, and growth in a fjord: a case study on lavae of the sand dollar Dendraster excentricus. Mar Ecol Prog Ser 31:245-254

Foreman RE (1977) Benthic community modification and recovery following intensive grazing by Strongylocentrotus droebachiensis. Helgol Wiss Meeresunters 30:468-484

Gaines SD, Bertness M (1993) The dynamics of juvenile dispersal: why field ecologists must integrate. Ecology 74 : $2430-2435$

Guillou M, Michel C (1993) Reproduction and growth of Sphaerechinus granularis (Echinodermata: Echinoidea) in southern Brittany. J Mar Biol Ass UK 73:179-192

Harris LG, Chester CM (1996) Effects of location, exposure and physical structure on juvenile recruitment of the sea urchin Strongylocentrotus droebachiensis in the Gulf of Maine. Invertebr Reprod Dev 30:207-215

Harrold C, Lisin S, Light KH, Tudor S (1991) Isolating settlement from recruitment of sea urchins. J Exp Mar Biol Ecol 147:81-94

Hart MW, Scheibling RE (1988). Heat waves, baby booms, and the destruction of kelp beds by sea urchins. Mar Biol 99:167-176

Heath RA (1974) Physical oceanographic observations in the Marlborough Sounds. NZ J Mar Freshw Res 8:691-708

Hughes TP (1990) Recruitment-limitation, mortality, and population regulation in open systems: a case study. Ecology 71:12-20

Keesing JK, Hall KC (1998) Review of harvests and status of world sea urchin fisheries points to opportunities for aquaculture. J Shellfish Res 17(5):1597-1604

Keesing JK, Cartwright CM, Hall KC (1993) Measuring settlement intensity of echinoderms on coral reefs. Mar Biol 117: 399-407

Keough MJ, Downes BJ (1982) Recruitment of marine invertebrates: the role of active larval choices and early mortality. Oecologia 54:348-352

Lamare MD (1997) Population biology, pre-settlement processes and recruitment in the New Zealand sea urchin, Evechinus chloroticus Valenciennes (Echinoidea: Echinometridae). $\mathrm{PhD}$ Thesis, University of Otago, New Zealand

Lamare MD (1999) Origin and transport of larvae of the sea urchin Evechinus chloroticus (Echinodermata: Echinoidea) in a New Zealand fiord. Mar Ecol Prog Ser 174:107-121

Lamare MD, Barker MF (1999) In situ estimates of larval development and mortality in the New Zealand sea urchin Evechinus chloroticus (Echinodermata: Echinoidea). Mar Ecol Prog Ser 180:197-211

Lamare MD, Mladenov PV (2000) Modelling somatic growth in the sea urchin Evechinus chloroticus (Echinoidea: Echinometridae). J Exp Mar Biol Ecol 243:17-43

McShane PE, Anderson O, Gerring P, Stewart R, Naylor JR (1994) Fisheries biology of kina (Evechinus chloroticus). New Zealand Fisheries Assessment Research Document No. 94/17. MAF Fisheries, NZ Ministry of Agriculture and Fisheries

Miller BA, Emlet RB (1997) Influence of nearshore hydrodynamics on larval abundance and settlement of sea urchins Strongylocentrotus franciscanus and $S$. purpuratus in the Oregon upwelling zone. Mar Ecol Prog Ser 148:83-94

Miller BA, Emlet RB (1999) Development of newly metamorphosed juvenile sea urchins (Strongylocentrotus franciscanus and $S$. purpuratus): morphology, the effects of temperature and larval food ration, and a method for determining age, J Exp Mar Biol Ecol 235:67-90

Mladenov PV, Allibone RM, Wallis GP (1997) Genetic differentiation in the New Zealand sea urchin, Evechinus chlo- 
roticus (Echinodermata: Echinoidea). NZ J Mar Freshw Res 31:261-269

Pearce CM, Scheibling RE (1990) Induction of metamorphosis of larvae of the green sea urchin, Strongylocentrotus droebachiensis, by coralline red algae. Biol Bull 179:304-311

Pearce CM, Scheibling RE (1991) Effect of macroalgae, microbial films, and conspecifics on the induction of metamorphosis of the green sea urchin Strongylocentrotus droebachiensis (Muller). J Exp Mar Biol Ecol 147:147-162

Pearse JS, Hines AH (1987) Long-term population dynamics of sea urchins in a central California kelp forest: rare recruitment and rapid decline. Mar Ecol Prog Ser 39: 275-283

Pickard GL, Emery WJ (1982) Descriptive Physical Oceanography. An introduction. Pergamon Press

Rowley RJ (1989) Settlement and recruitment of sea urchins (Strongylocentrotus spp.) in a sea-urchin barren ground and a kelp bed: are populations regulated by settlement or post-settlement processes? Mar Biol 100:485-494

Rowley RJ (1990) Newly settled sea urchins in a kelp bed and urchin barren ground: a comparison of growth and mortality. Mar Ecol Prog Ser 62:229-240

Editorial responsibility: John Lawrence (Contributing Editor), Tampa, Florida, USA
SAS Institute Inc. (1987) Guide for personal computers, Version 6 Edition. SAS Institute Inc., Cary, NC, p 1028

Tegner MJ, Dayton PK (1981) Population structure, recruitment and mortality of two sea urchins (Strongylocentrotus franciscanus and $S$. purpuratus) in a kelp forest. Mar Ecol Prog Ser 5:255-268

Underwood AJ, Fairweather PG (1989) Supply-side ecology and benthic marine assemblages. Trends Ecol Evol 4: $16-20$

Vance RR (1980) The effect of dispersal on population size in a temporally varying environment. Theor Popul Biol 18:343-362

Vance RR (1984) The effect of dispersal on population stability in one-species, discrete-space population growth models. Am Nat 123:230-254

Williamson JE, De Nys R, Kumar N, Carson DG, Steinberg PD (2000) Induction of metamorphosis in the sea urchin Holopneustes purpurascens by a metabolite complex from the algal host Delisea pulchra. Biol Bull 198:332-345

Wing SR, Largier JL, Botsford LW, Quinn JF (1995) Settlement and transport of benthic invertebrates in an intermittent upwelling region. Limn Oceanogr 40:316-329

Submitted: November 18, 2000; Accepted: May 28, 2001 Proofs received from author(s): July 25, 2001 